\title{
Impact of Virtual Teaching on ESL Learners' Attitudes under Covid-19 Circumstances at Post Graduate Level in Pakistan
}

\author{
Syed Khuram Shahzad ${ }^{1}$, Javaid Hussain ${ }^{2}$, Nadia Sadaf ${ }^{3}$, Samina Sarwat ${ }^{3}$, Usman Ghani $^{3} \&$ Robina Saleem ${ }^{3}$ \\ ${ }^{1} \mathrm{PhD}$ Scholar in English, Linguistics, Sindh University, Jamshoro, Pakistan \\ ${ }^{2}$ National College of Business Administration \& Economics Lahore, Pakistan \\ ${ }^{3}$ Khawaja Fareed University of Engineering and Information Technology Rahimyar Khan, Pakistan \\ Correspondence: Syed Khuram Shahzad, Akbar Town, Street No, 02, House No.03, Dist. Rahimyar Khan, \\ Tehsil Sadiqabad, Pakistan.
}

Received: July 8, 2020

Accepted: July 25, 2020

Online Published: August 4, 2020

doi: 10.5539/elt.v13n9p1

URL: https://doi.org/10.5539/elt.v13n9p1

\begin{abstract}
Covid-19 proved a pandemic that has affected the whole world on a large scale. Every walk of life got disturbed by this pandemic. Educational institutions not only in Pakistan but all over the globe remain close, which causes a loss of study for the students of all Grades, notably Higher education (Postgraduate Level), which directly affected education, learners, and teachers in terms of learning, time, and economically. Virtual Teaching (VT) is proving an emerging method of teaching in the field of education all over the world. Developed countries have opted for this method of teaching much before. In Pakistan, universities under the directions of HEC started Virtual Teaching VT (Online Teaching) for the students, which was an attempt to cover the loss on an experimental basis. This study is conducted to know the impact of VT on ESL students' behavior. For this purpose among 100 students of KFUEIT, RYK University distributed a questionnaire to measure their behavior level. Students' participation was inspiriting, and their response found positive in this new field of Teaching.
\end{abstract}

Keywords: Covid-19, Virtual Teaching, HEC Pakistan, attitude, ESL

\section{Introduction}

The invention of personal computers and laptops has revolutionized the entire world. Facebook, Twitter, Skype, and Instagram have provided people with a new way of communication. People communicate and share their ideas across the globe with the help of these programs and applications. Teachers and instructors offer online programs for learners. Virtual Teaching (VT) is a way of Teaching that is experienced by utilizing computer/related technology, and the Internet within and outside educational institutions. In virtual teaching instructions most commonly takes place in an online environment. Teachers and learners do not come and join face to face with each other at the same place. They both are physically separated in terms of time, place, and or both. In this method of Teaching, activities are carried out. The world is adopting this method of Teaching due to the change in the priorities of the people. VT may be a step to provide education on the doorstep to the learners, which may increase the literacy rate. Sometimes circumstances may force to adopt this method of Teaching. Students and teachers may facilitate each other in terms of time management as they can set their required time for the online class.

\subsection{The Statement of the Problem}

These are the days of COVID-19, and almost the countries of the world are changing their styles of living, governance, education, interaction, etc. The central theme of all these styles changing is ' social distancing,' which is currently the only precautionary cure of this pandemic. The norms of education are also changing according to the slogan of social distancing. In other words, the leaning has changed its mode from face to face to virtual or online. English language learning is a little bit different from the other traditional type of Teaching. It also goes on virtual as other ways of education. The problems arise whether the online or virtual learning of the English language will be useful or not. How will students consider it? Will the virtual learning change or modify the attitudes of the student towards English as a second language, etc. The present study is all about the attitudes of ESL learners towards online learning. Learning a second language is always an engaging activity and has a positive relationship with the students (Stern, 1987). Values are very much crucial for the attitudes as these form the basis of our attitudes (Wright, 1987). We have all sorts of attitudes, whether positive or negative, as these are based on values. If a student wants to master the foreign language and gives importance to that, it means that he or she is giving importance and priority to that language. It shows his or her positive attitude towards that language. 


\subsection{Significance of the Study}

Online Teaching has become part and parcel and needs the hour for not only the world but also for Pakistan. It is in the initial stages of Pakistan. The recent pandemic wave of COVID-19 has disturbed almost every walk of life worldwide. It also has affected higher education severely. Virtual Teaching has already been used in developed countries. Now, the Higher education commission of Pakistan is also moving to this system on an experimental basis to minimize the loss of education. As this is implemented on a pilot basis so, there may be some difficulties in implementing it in universities. This research project is also a chain of this project. The government and other educational organizations had design policies for online learning to implement in the education field at the university level. Still, due to less knowledge about ground realities, the policies fail to achieve the desired outcomes. Several pieces of research were made on various online learning dimensions, i.e., barriers and impact of online learning in the students' academic achievements, but the least study was made on the attitude of students towards online learning. Moreover, the studies were made at secondary and intermediate levels, but no formal efforts were made to research the undergraduate level. As the undergraduate level is a crucial stage in academics and the students are more motivated and energetic at this level to perform actual research work, therefore, to know their attitude regarding online learning is of great importance.

\subsection{Objectives of the Study}

i. To find students' interest in virtual Teaching at the postgraduate level.

ii. To examine the efficiency of virtual Teaching and its impact on students; attitude.

1.4 Research Questions

i. How does Virtual Teaching affect students' attitudes?

\section{Virtual Teaching}

The literal meaning of the word 'virtual' is 'the possible' taken from the Latin word "virtualis." Several circumstances and conditions influence the possibilities. (Podhajecka, 2018)This virtual process is not the actual or real process; instead, it happens in the place of an existing system having similar dynamics and aspirations.

Due to COVID-19, UNESCO (United Nations Educational, Scientific, and Cultural Organizations) suggested that educational institutions adopt Virtual Teaching based on social distancing (Bansal, 2020). It is alternate to the face to face or traditional Teaching. Online or virtual Teaching is an online teaching process in which there is no physical participation of the teachers and students is mandatory and, they are located in different separate locations at the time of the teaching process (Sanford, 2020). It is also possible that the participants are separated concerning time (Smyrnova-Trybulska, Kommers, Morze, \& Malach, 2019). As the word, 'virtual' suggests to 'possible,' so it becomes essential to complete the teaching process by modifying according to the given circumstances.

The online educational environment faces some technical and methodological problems of information sharing and management. The primary functions of the virtual education process are communication, information sharing, and management or administration. For the virtual learning environment, the technologies, computer tools, and other IT sources have used that control the education environment, participants, and authenticity of communication (Gadre, Cudney, \& Corns, 2011).

The educational institutions link the teachers and the students through some internal or external websites or any 'learning management systems (Crawley, 2012). It depends on the availability of the resources that an institution has. There are many online applications for the fulfillment of the task; someone is free while some are paid. The institutions, according to their needs and budget, avail them accordingly. If the existing online applications fail to satisfy the needs, then they can arrange to make new ones from the software engineers. These all tools fall in the category of virtual or online learning management system (Crawley, 2012) These online learning management system needs to have proper and relevant training of all the stakeholders of the teaching-learning process as teachers and students. Moreover, online teaching applications must be ensured regarding their reliability and authenticity because these are the only sources of connectivity between the stakeholders. If these seizures to work, the whole online teaching process will collapse instantly.

In the virtual teaching process, all the participants log in simultaneously online, and the single teacher or instructor delivers the teaching material in the form of the lecture. All the stakeholders of this process are involved in the process where information, discussion, question answering activity, etc. are practiced. That is all called collaborative group-based learning. Here all the participants work as a community of practice, sharing common concerns of information sharing and discussion (Mezirow, 2000; Salmon, 2004; Schön, 1987; Wenger, 1999).

Virtual learning has both pros and cons. The advantages of this process are

- Cost saving in terms of time, money, and travel.

- Free from any time and location restrictions. The class can be taken at any time and in any place. 
- Mostly, the lectures comprise pre-recorded videos that can be stopped, reversed, forwarded, downloaded, and watch as many times someone needs.

- Virtual discussion can be made quickly.

- Exposure with technology.

- No discrimination with regards to race, sex, communities, nationality, religion, etc.

- Ensures active and impartial learning.

- Disadvantages of virtual learning can be.

- Improper assessment of the students.

- Poor monitoring.

- Lack of teacher-student, student to student interaction.

- Other social activities cannot be performed.

- Learning always at stake due to poor web connections and application.

- No alternate way of Teaching.

- All the students are not ready to accept online learning.

- Unavailability of online facilities to all students, especially in remote areas.

- Disciplinary issues.

- It enhances social isolation.

- Focus is on theory, not on the practice.

- Lesser questioning answering activities.

- Lack of corrections of mistakes immediately.

- No control over unethical problems.

\subsection{ESL Learners Attitudes towards Virtual Learning}

Attitudes have got enough attention from all the researchers, including first and second language. They consider attitude one of the main aspects that affect language learning. They believe that the students cannot learn the second language if they have no positive attitude toward it. So attitude is the essential component in the learning of the second language. As English is an international language, even it is the official language of most of the countries, so all the competitive exams are held in English in those countries. English has become the need of the time and guarantees for the students' future, so students give utmost preference to the English as compared to other foreign languages. Many factors affect English language learning as a second language. According to Kaballa and Crowley cited in (Weinburgh, 1998) that students tend to select and read a book of the foreign language and try to speak in that language as well. Every individual is different in approach and cognition - different stimuli affect the attitudes of every individual. According to stern (Jarvis, 1985), that the cognitive aspect of language learning is more effective than the other ordinary skill in the students. When a student considers second language learning as a matter of his future and life, then his skills work maximum, almost all the studies have consensus over it that the success of language learning is influenced by affective variables (Eveyik, 1999; Gardner et al., 1985; Skehan, 1989; Spolsky, 1989). Students' attitudes vary from time to time, according to the circumstances. However, students are always ready to learn the language. These are the days of COVID-19, and the face to face language learning is halted. The language learning institutes have adopted virtual or online classes to meet the requirement as it is a new trend in language learning, so the attitudes of the students about virtual learning vary from student to student. Every student wants to learn English as a second language, but everyone has not accepted the virtual learning of the English language. However, instead, they have different securities on the matter. Virtual learning is quite different from the face to face learning. It is different in terms of the classroom environment, the actual presence of the teachers and the student, social interaction, etc. moreover, it requires IT directly too. The current scenario is vague to the students as all the students are not trained accordingly and not have the IT facility equally, so they have some genuine concerns about it. These concerns have changed the velocity of their attitudes.

\subsection{Impact of COVID-19 on Education/Teaching}

The world has been changing continuously and making development almost in every sector regardless of the momentum of its progress. This process is called evolution.

There can be numerous factors that bring about evolution as environmental, geographical, religious, wars and Pandemics, etc. The base of every progress is education and knowledge, which we not only learned but also shared with others. In other words, education is a teaching and learning exercise. There is a difference between an ordinary and an institutional type of education. This type of education involves teacher, institution, and 
learner or student majorly. The conventional method of Teaching is called face to face or traditional. Here there is a classroom, a teacher, and students. The teachers teach the students to face to face in their actual presence with the teaching material provided by the administration of the institution. As mentioned above, Pandemics are significant factors of evolution. The major pandemics are Black Death (1346-1353), Spanish Flu (1918-1920), and Swine Flu (2009-2010). These influenced so much the society that the world had to change its way of living, governance, business, and education etc. is the era of the Covid-19 Pandemic. It is the most widespread among all the pandemics and has surrounded almost the whole world, and still, it is prevailing with its intensity.

COVID-19 has affected almost every sector of life; even it did not spare the field of education. Before this pandemic, there was a traditional way of teaching to the students, as said face to face teaching. Students used to go to their respective educational institutions like schools, colleges, universities, etc. Where they were present physically in the classroom along with their teacher and were taught with active participation. Then COVID-19 started to spread, and it was suggested by the WHO (World Health Organization) to ensure 'social distancing' as the foremost precautionary measure along with other measures as wearing the mask, etc. The precaution of social distancing was adopted by almost every institution. Almost all the countries went on 'lockdown' and halt their businesses (Gandolfi, 2020). A majority of them adopted the virtual presence of their workforce- the WHO took quite seriously the children and suggested the governments to close their educational institutions. For the timely solution of the problem, UNESCO (United Nations Educational, Scientific, and Cultural Organization) suggested the virtual learning programs and using different educational applications and locations so the teachers may deliver their lectures to their respective students remotely (Bansal, 2020).

Then considering education continuity quite severe, the governments appreciated the concept and technique of virtual or online Teaching. In virtual Teaching, the teachers and the students are not present physically in the same class; instead, they remain separate different locations and connect via different IT (Information Technology) applications. The concept of virtual Teaching is very much practical in these specific days. Moreover, there seems no end of this pandemic shortly, as mentioned by the different Health organizations across the globe. The closure of the school affected almost every stakeholder as teachers, students, and their families (Bao, Qu, Zhang, \& Hogan, 2020).

Here a searching question arises that whether virtual Teaching can be the best replacement of the traditional face to face teaching in terms of quality education and results in orientation? Virtual Teaching can fulfill only a limited number of requirements for the learning process. Teaching is not a narrow process. In other words, it does not provide the course outlines and exams to students; instead, it creates an environment of competition, provides opportunities for growth development. These aspects of education can only be obtained through face to face teaching.

Moreover, there are numerous problems of virtual Teaching as a teacher and student interaction and vice versa, student to student interaction, lack of classroom environment, technical issues, unavailability of IT equipment to every student, proper and relevant training of virtual Teaching and learning to teachers and the students, lake of monitoring of the classroom, improper questioning answering, etc. Due to these significant shortcomings, the closure of the educational institutions, and the absence of the face to face teaching, learning outcomes of the students are producing a negative impact (Lindzon, 2020). The majority of the students do not continue their learning activities beyond the school as they require a classroom environment; only a few students do that. Schools are not just the buildings for course teaching and learning instead of centers of social activities in which they learn equally about human behaviors by interacting with one another along with their course work (Bansal, 2020; Mustafa).

\section{Papulation and Sampling}

This study was conducted in District Rahimyar Khan of Province Punjab, which is situated in the Southside of Punjab and called Southern Punjab. Two major Universities Khawaja Freed University of Engineering and Technology and Islamiyah University Bahawalpur (Campus) situated here with multi-disciplines. The study was conducted in the English department of KFUEIT, and a questionnaire was distributed among 100 students.

\subsection{Methodology}

An experimental approach was used for this study. The analysis was made qualitatively as well as quantitatively. A questionnaire was developed based on 30 items. It was constructed on five Likert-scale and closed-ended, having options Strongly Agreed (SA), Agreed (A), Undecided (UND), Disagreed (D), and Strongly Disagreed (SD). A Questionnaire was distributed among the students by sending them through WhatsApp as there were no classes and Universities were closed due to wave of pandemic Corona Virus (COVID-19) among 100 participants through random and convenient sampling. 


\subsection{Data Analysis and Data Interpretation}

Table 1. Responses to Questionnaire about Virtual Teaching

\begin{tabular}{|c|c|c|c|c|c|c|}
\hline No. & Statement & 1 & 2 & 3 & 4 & 5 \\
\hline 1 & Virtual learning is enjoyable for the learners & 32 & 43 & 0 & 21 & 4 \\
\hline 2 & $\begin{array}{l}\text { Students are compelled to learn through } \\
\text { virtual Teaching in specific circumstances }\end{array}$ & 28 & 47 & 7 & 13 & 5 \\
\hline 3 & $\begin{array}{l}\text { Virtual Teaching is better than face to face } \\
\text { Teaching }\end{array}$ & 5 & 15 & 0 & 54 & 26 \\
\hline 4 & Virtual learning is problematic & 11 & 14 & 5 & 55 & 15 \\
\hline 5 & $\begin{array}{l}\text { Face to face teaching is better than virtual } \\
\text { Teaching }\end{array}$ & 26 & 54 & 0 & 15 & 5 \\
\hline 6 & $\begin{array}{l}\text { Virtual Teaching can be helpful only in } \\
\text { particular circumstances }\end{array}$ & 22 & 32 & 8 & 14 & 24 \\
\hline 7 & $\begin{array}{l}\text { The teacher is easily accessible in virtual } \\
\text { Teaching }\end{array}$ & 30 & 35 & 0 & 16 & 19 \\
\hline 8 & $\begin{array}{l}\text { Virtual Teaching fulfills language learning } \\
\text { needs }\end{array}$ & 18 & 24 & 14 & 34 & 10 \\
\hline 9 & $\begin{array}{l}\text { Virtual Teaching is carried out without any } \\
\text { interruption }\end{array}$ & 25 & 28 & 11 & 22 & 14 \\
\hline 10 & $\begin{array}{l}\text { Audio-video quality is satisfactory for } \\
\text { virtual learning }\end{array}$ & 13 & 7 & 2 & 29 & 49 \\
\hline 11 & $\begin{array}{l}\text { Every student has facility to avail virtual } \\
\text { lectures }\end{array}$ & 11 & 16 & 5 & 53 & 15 \\
\hline 12 & Teachers are trained for virtual Teaching & 26 & 27 & 11 & 22 & 14 \\
\hline 13 & $\begin{array}{l}\text { Relevant training is provided to students for } \\
\text { virtual learning }\end{array}$ & 12 & 13 & 5 & 51 & 19 \\
\hline 14 & $\begin{array}{l}\text { The instructions of the teacher are easily } \\
\text { understandable for the students in virtual } \\
\text { learning }\end{array}$ & 27 & 23 & 12 & 20 & 18 \\
\hline 15 & $\begin{array}{l}\text { Every student is ready to get virtual } \\
\text { Teaching }\end{array}$ & 24 & 26 & 14 & 20 & 16 \\
\hline 16 & $\begin{array}{l}\text { Every student has equal cognition } \\
\text { capacity/ability to get virtual teaching }\end{array}$ & 12 & 13 & 5 & 47 & 23 \\
\hline 17 & $\begin{array}{l}\text { The availability of the Internet is ensured at } \\
\text { any time for all the students }\end{array}$ & 28 & 48 & 0 & 14 & 10 \\
\hline 18 & Virtual learning engages the students & 32 & 36 & 7 & 21 & 4 \\
\hline 19 & $\begin{array}{l}\text { All the students actively participate equally } \\
\text { in the virtual learning }\end{array}$ & 25 & 23 & 12 & 22 & 18 \\
\hline 20 & Students are afraid of virtual learning & 26 & 27 & 11 & 22 & 14 \\
\hline 21 & Virtual teaching ensures quality learning & 25 & 23 & 12 & 22 & 18 \\
\hline 22 & Virtual teaching maintains students retention & 25 & 44 & 10 & 13 & 8 \\
\hline 23 & $\begin{array}{l}\text { Students do not pay attention properly in the } \\
\text { virtual learning }\end{array}$ & 26 & 39 & 4 & 16 & 15 \\
\hline 24 & $\begin{array}{l}\text { Students face emotional and behavioral } \\
\text { problems in virtual learning }\end{array}$ & 27 & 41 & 8 & 14 & 10 \\
\hline 25 & $\begin{array}{l}\text { Ethical rules are observed in the virtual } \\
\text { learning }\end{array}$ & 49 & 21 & 5 & 11 & 14 \\
\hline 26 & $\begin{array}{l}\text { Teaching material is relevant for the virtual } \\
\text { learning }\end{array}$ & 27 & 29 & 8 & 22 & 14 \\
\hline 27 & $\begin{array}{l}\text { Students are informed before virtual } \\
\text { learning }\end{array}$ & 42 & 28 & 0 & 17 & 13 \\
\hline 28 & $\begin{array}{l}\text { Question answering activity is performed } \\
\text { easily in the virtual learning }\end{array}$ & 22 & 32 & 8 & 14 & 24 \\
\hline 29 & Virtual Teaching is performed daily & 42 & 45 & 0 & 7 & 6 \\
\hline 30 & Virtual teaching is best for ESL learning & 23 & 26 & 17 & 26 & 8 \\
\hline 31 & $\begin{array}{l}\text { Virtual Teaching modifies the attitudes of } \\
\text { the students }\end{array}$ & 26 & 29 & 9 & 19 & 17 \\
\hline
\end{tabular}


All 100 students participated and responded to the questionnaire, in response to Q.No.1. Thirty-two students were strongly agreed, 43 agreed, 0 neutral, 21 disagree, and 4 strongly disagree with the statement. It means that the majority of the students enjoyed virtual Teaching - students who do not enjoy Virtual Teaching less in number according to received responses. Hence, Virtual Teaching is enjoyable for the learners.

In response to Q.No.2. One hundred studded expressed their opinion regarding this question. 28 students were strongly agreed, and 54 agreed that students are compelled to learn through virtual Teaching in specific circumstances. According to responses, 0 students were undecided, 13 disagreed, and 5 were strongly disagreed with the statement. It means that maximum students think students are compelled to learn through virtual Teaching in specific circumstances.

Students' opinion regarding the Q.No.3 question shows that the majority of the students in the favor that face to face teaching is better than virtual or online Teaching. 5 students strongly agreed, 15 students' agreed, 7 students did not show their concern about the statement, whereas 47 disagreed, and 26 strongly disagreed. Mostly students' have disagreed with the statement so, it could be concluded that face to face teaching is better than Encouraging Virtual Teaching.

In response to Q.No.4, the majority of the students disagreed with this statement. According to the majority of the students, virtual learning is not problematic. 11 students were strongly agreed, 14 were agreed, 0 undecided, 55 disagreed, and 20 strongly disagreed with this statement.

In response to Q.No.5. Learners' opinion regarding this statement shows that they are more satisfied with learning through face to face teaching technique than Virtual Teaching (VT). According to 26 students, they were strongly agreed that face to face teaching is better than that of virtual Teaching. 54 students are agreed, 0 undecided, 15 students disagreed, and 5 students were strongly disagreed with this statement.

Students' trend towards this statement about Q.No.6, was positive. 22 students strongly agreed, 33 agreed, 8 students were remained undecided, whereas 14 students disagreed, and 23 students were strongly disagreed with this statement. The majority of the students were in favor of the statement that Virtual Teaching is helpful only in particular circumstances.

In response to Q.No.7. The statement, students responded with strong "Yes" According to students, the teachers are in their approach in online Teaching. 30 students were strongly agreed, 35 were agreed, undecided wee 0,16 disagreed, and several students who were strongly disagreed, nineteen.

The student's response towards this statement of Q.No.8 was strange. About half of the total students did not show any response, and they (48 students) selected the option "undecided" for this statement. Anyhow, 18 students were strongly agreed. 24 were agreed, 0 students disagreed, and 10 students were strongly disagreed.

In response to Q.No.9's statement, 25 students were strongly agreed, 28 were agreed, 11 were undecided, 22 students disagreed, and 14 students were strongly disagreed. Though students' responses against this statement found mix, little students are more in the number who were strongly agreed and agreed than those who were disagreed or strongly disagreed.

In response to Q.No.10, Students showed their concern in response to this statement. According to them, Audio and Video quality did not feel satisfied. They might find interruption or poor internet quality. Out of 100 students, 13 were strongly agreed, 7 were agreed, 2 were undecided, 32 disagreed, and 46 students were strongly disagreed.

Facts collected about Q.No.11 represented that most of the students were lacking the facility to avail of virtual lectures. 10 students were strongly agreed, 16 agreed, 5 undecideds, 54 students wer3are disagreed, and 15 students were strongly disagreed with this statement.

Again students seem careful in response to the statement to Q.No.12, as there is less difference of opinion among students. 26 students were strongly agreed, 28 students were agreed, 11 were undecided, 21 disagreed and, 14 were strongly disagreed about this statement.

The lion's share of the students was not accepting this statement of the Q.No.13. According to their opinion students were not provided with necessary training. 12 students were strongly disagreed, 13 students were agreed, 5 students were undecided, and 50 disagreed, and 20 students strongly disagreed.

According to this statement of Q.No.14, 26 students were strongly agreed, 24 students were agreed, 12 were undecided, 20 disagreed, and 18 students were strongly disagreed. Most of the students were in favor of the statement. 
Responses received about the statement of Q.No.15, shows that more students have shown their interest in virtual learning. 24 students were strongly agreed, 26 students were agreed, 14 students were undecided, 20 students disagreed, and 16 students were strongly disagreed.

Results regarding the statements of Q.No.16 show that students disagree with this statement. According to them, students do not possess equal cognitive ability to understand what was taught through VT. It means that some students can understand completely, some partially and some below of all while learning through VT. 12 students were strongly agreed with the statement, 13 students were agreed, 5 were undecided, 48 disagreed, and 22 students were strongly disagreed.

The Internet has critical importance for conducting online classes. So, the availability of the Internet must be ensured before conducting VT. In response to the Q.No.17, statement, 28 students were strongly agreed, 48 students were agreed, 0 undecided, 14 disagreed, and 10 students' were strongly disagreed.

In reply to the Q.No.18, Out of 100, 32 students have the opinion and strongly agreed that VT engages the students towards keeping their focus on teachers' lectures. 36 students were agreed, 7students were undecided, 21 disagreed, and 4 students were strongly disagreed.

In response to the Q.No.19 statement, 26 students were strongly agreed, 23 students were agreed, 12 students were undecided, 22 disagreed, and 17 students were strongly disagreed with this statement. It means that a large portion of students actively participates equally in virtual learning.

Results of Q.No.20 display that students are afraid of virtual learning. Its cause may be a lack of resources like a computer, laptops, the Internet, or other related technology. 26 students were strongly disagreed, 28 students were agreed, 11 students were undecided, 22 disagreed, and 13 were strongly disagreed with this statement.

In response to the Q.No.21, 25 students were strongly disagreed, 23 students were agreed, 12 students remained undecided, 21 students disagreed, and 19 students were strongly disagreed with this statement—majority of the students' opinion that virtual Teaching ensures quality leaning.

Most of the students are agreed that virtual Teaching maintains students' retention. Students do not remain absent from attending online classes as compared to face to face to the classroom. About Q.No.22's statement, 25 students were strongly agreed, 44 students were agreed, 10 students were undecided, 13 students disagreed, and 8 students were strongly disagreed with the text.

The majority of the students disagreed with the statement of Q.No.23. According to the students, VT allows them to pay proper attention to lectures and learning. 16 students were strongly disagreed with the statement, 15 students disagreed, 4 students were undecided, 26 disagreed, and 39 were strongly disagreed with the students.

In response to the Q.No.24, 27 students strongly agreed, 41 agreed, 8 undecideds, 14 disagreed, and 10 students have strongly disagreed. The majority of the students agreed that VT brings an emotional and behavioral change in students.

In reply to Q.No.25's statement, most students are in favor that ethical rules are observed in virtual learning. 49 students were strongly agreed, 21 students agreed, 5 undecideds, 11 disagreed, and 14 students were strongly disagreed.

Most of the students are in the favor that teaching material is relevant to the lecture while VT class is being conducted. In reply to Q.No.26, 27 students strongly agreed, 30 students agreed, 7 undecideds, 23 disagreed, and 13 have strongly disagreed with the statement.

While replying to Q.No.27, students' opinion that during the VT class teacher asks a question from any of the students of his choice to check and assess them. Students can ask the question to clear their idea or learning as well.

In response to this Q.No.28, a large number of students have accepted that question-answering activity is performed quickly in virtual learning. 42 students were agreed with the statement, 28 were agreed, 0 were undecided, 17 disagreed, and 13 students were strongly disagreed with the statement.

In reply to the Q.No.29, the majority of the students accepted that like face to face teaching; VT can be conducted daily. 42 students strongly greed, 45 were agreed, 0 were undecided, 7 students have disagreed, and 6 students strongly disagreed with this statement.

The majority of the students' about Q.No.30, admit that VT is useful for ESL teaching and learning. 28 students strongly agreed, 26 students agreed, 17 students undecided, 22 students disagreed, and 7 students strongly disagreed with the text. 
In reply to Q.No.31, the majority of the students accept that VT brings a change in students learning behavior and attitude. 26 students strongly agreed, 29 students agreed, 9 undecideds, 19 disagreed, and 17 strongly disagreed with the statement.

\subsection{Conclusion}

The results of the study reveal that Virtual Teaching (VT) brings a positive change in students' attitudes. Students are committed and motivated towards their studies, and they welcome Virtual Teaching (VT) under COVID-19 circumstances. A big part of the students favors online Teaching as it is a new but happy experience for them. They seem excited about learning through online Teaching. They express their convenience while learning and attending lectures through VT. According to them, teachers are easily accessible, they can ask questions by voice or text messages, and the teacher replies to them at the spot when online class is being conducted or later in his free time.

Moreover, with consulting with their teacher and other fellows, they can manage a specific time for the online class, which is convenient for them. In this way, maximum students who cannot be able to attend traditional or face to face lectures can quickly attend all the lectures and or can get the recorded video lectures if recorded. In this way, the majority of the students can take advantage of attending the lectures. VT also help students to save their time and money as well. Students in remote areas and other cities can save their time as they do not need to cover a long distance and pay travel or hostel expenses. Students can stay with their family and relatives. To conclude all, it cannot be an exaggeration to say that VT may provide ease, happiness, and confidence to the students and removed worriedness and frustration.

Meanwhile, on the contrary, it has some drawbacks as well. Though there is a lack of facilities in the Pakistani environment about which they have shown their concerns, for example, the problem of internet connectivity, deficiency of resource material, lack of technology, etc. All the students are not experts in the use of technology. Students may be provided with introduction and orientation regarding the use of technology. However, these lacks may be overcome over time. Sometimes they feel interruption in video and audio quality. The majority of the students' opinions that the teaching-learning process should be continued under any situation and use of technology in this process may prove a milestone in the current situation as well as in the future.

\subsection{Recommendations}

In light of the above discussion and conclusion, the following recommendations have been drawn for the betterment, positive, and constructive role of VT.

i. It has been observed that the world has opted for VT objectively, with some purpose. However, in Pakistan, it has opted just for the need-based situation under pandemic COVID-19 scenario, so, it is recommended that Govt. of Pakistan and with HEC and other stakeholders make a comprehensive plan to implement VT not only on the higher level of education but also on the higher secondary, secondary and elementary and primary level.

ii. VT should be used objectively on a priority basis.

iii. Universities, Colleges, and Schools should be provided with the Internet and the proper latest technology which is used in VT.

iv. Teachers and students should be provided with necessary training regarding VT for active learning.

v. Students will also be facilitated with computer and other resources used in VT.

vi. E-teaching and learning are trending in the world, so, effective strategies should be made to promote in Pakistan.

Vii. Govt. should provide funds for its implementation in all over Pakistan.

viii. Seminars should be conducted for its promotion and awareness among teachers and students.

\section{References}

Bansal, S. (2020). Impact of the COVID-19 Pandemic on Education, Rise of Online Teaching-Learning Process \& Effects on Health of Kids. Rise of Online Teaching-Learning Process \& Effects on Health of Kids (May 8, 2020). https://doi.org/10.2139/ssrn.3595971

Bao, X., Qu, H., Zhang, R., \& Hogan, T. P. (2020). Literacy Loss in Kindergarten Children during COVID-19 School Closures. https://doi.org/10.31235/osf.io/nbv79

Crawley, A. (2012). Supporting online students: A practical guide to planning, implementing, and evaluating services: John Wiley \& Sons. 
Eveyik, E. (1999). Development of an attitude scale to investigate Turkish EFL teacher attitudes. Basilmamis Yuksek Lisam Tezi. Istanbul. https://doi.org/10.19128/turje.426051

Gadre, A., Cudney, E., \& Corns, S. (2011). Model development of a virtual learning environment to enhance lean education. Procedia Computer Science, 6, 100-105. https://doi.org/10.1016/j.procs.2011.08.020

Gandolfi, A. (2020). Planning of School Teaching during COVID-19. arXiv preprint arXiv:2006.03672.

GARDNER, R. C. (1985). Social psychology and second language learning: The role of attitudes and motivation.

Jarvis, G. (1985). FUNDAMENTAL CONCEPTS OF LANGUAGE TEACHING. HH Stern. Oxford: Oxford University Press, 1983. Studies in Second Language Acquisition, 7(2), 251-253. https://doi.org/10.1017/S0272263100005416

Lindzon, J. (2020). School closures are starting, and they'll have far-reaching economic impacts. Fast Company, $11-13$.

Mezirow, J. (2000). Learning as Transformation: Critical Perspectives on a Theory in Progress. The Jossey-Bass Higher and Adult Education Series: ERIC.

Mustafa, N. IMPACT OF THE 2019-20 CORONAVIRUS PANDEMIC ON EDUCATION.

Podhajecka, M. (2018). Russian loanwords in the Oxford English Dictionary revisited. Przeglad Rusycystyczny, 2(162), 133-158.

Salmon, G. (2004). The five-step model. E-moderating-the key to Teaching and learning online (2nd ed.). London: RoutledgeFalmer.

Sanford, D. R. (2020). The Rowman \& Littlefield Guide for Peer Tutors: Rowman \& Littlefield Publishers.

Schön, D. A. (1987). Educating the reflective practitioner.

Skehan, P. (1989). Individual differences in second language acquisition: Hodder Education.

Smyrnova-Trybulska, E., Kommers, P., Morze, N., \& Malach, J. (2019). Universities in the Networked Society: Cultural Diversity and Digital Competences in Learning Communities (Vol. 10): Springer. https://doi.org/10.1007/978-3-030-05026-9

Spolsky, B. (1989). Conditions for second language learning: Introduction to a general theory: Oxford University Press Oxford.

Weinburgh, M. (1998). Gender, ethnicity, and grade level as predictors of middle school students' attitudes toward science. Georgia State University.

Wenger, E. (1999). Communities of practice: Learning, meaning, and identity: Cambridge university press. https://doi.org/10.1017/CBO9780511803932

\section{Copyrights}

Copyright for this article is retained by the author(s), with first publication rights granted to the journal.

This is an open-access article distributed under the terms and conditions of the Creative Commons Attribution license (http://creativecommons.org/licenses/by/4.0/). 